\title{
Green Synthesis of Silver Nanoparticles from Phaseolus vulgaris L. Extracts and Investigation of their Antifungal Activities
}

\section{Phaseolus vulgaris L. Özütlerinden Gümüş Nanoparçacıkların Yeşil Sentezi ve Antifungal Etkinliklerinin İncelenmesi}

\author{
Ege Ediz $^{1 \oplus}$, Gülbin Kurtay ${ }^{2}$, Başar Karaca ${ }^{\circledR}$, ilker Büyük ${ }^{1}$, Fatma Şeyma Gökdemir ${ }^{3}$ and Sümer Aras $^{1 *}$ \\ ${ }^{1}$ Department of Biology, Faculty of Science, Ankara University, Ankara, Turkey. \\ ${ }^{2}$ Department of Chemistry, Faculty of Science, Ankara University, Ankara, Turkey. \\ ${ }^{2}$ Department of Molecular Biology and Genetics, Faculty of Science and Letters, Başkent University, Ankara, Turkey.
}

\section{ABSTRACT}

\begin{abstract}
The aim of this study was to synthesize silver nanoparticles (AgNPs) using leaf, root, and stem extracts of Phaseolus vulgaris L. (Yunus-90) and elucidate their antifungal activities. In this regard, the prepared AgNPs have been characterized by using UV-vis, FT-IR, TEM, SEM, and DLS techniques. Then, the antifungal activity of both synthesized and commercially purchased AgNPs was investigated via (i) agar well diffusion, (ii) fungal colony morphotype diversity, (iii) inhibition of hyphae and (iv) minimum inhibition concentration (MIC) analyses against Colletotrichum sp., Fusarium oxysporum, Fusarium acuminatum, Fusarium tricinctum, Fusarium graminearum, Fusarium incarnatum, Rhizoctonia solani, Sclerotinia sclerotiorum, and Alternaria alternata. The AgNPs derived from the leaf extract displayed significantly higher levels of antifungal activity relative to the AgNPs prepared from the root and stem extracts. The commercial AgNPs also displayed lower antifungal activity than their green equivalents synthesized in this research, and even a low ( $50 \mu \mathrm{g} / \mathrm{mL}$ ) concentration of synthesized AgNPs was found to be effective in suppressing the growth of Fusarium tricinctum and Colletotrichum sp.
\end{abstract}

\section{Key Words}

Phaseolus vulgaris L., green synthesis, silver nanoparticle (AgNP), antifungal activity

öz

u çalışmanın amacı, Phaseolus vulgaris L.'nin (Yunus-90) yaprak, kök ve gövde özütlerini kullanarak gümüş

nanopartiküllerini (AgNPs) sentezlemek ve antifungal aktivitelerini ölçmektir. Bu bağlamda, hazırlanan AgNP'ler UVvis, FT-IR, TEM, SEM ve DLS teknikleri kullanılarak karakterize edilmiştir. Ardından hem sentezlenen hem de ticari olarak satın alınan AgNP'lerin Colletotrichum sp., Fusarium oxysporum, Fusarium acuminatum, Fusarium tricinctum, Fusarium graminearum, Fusarium incarnatum, Rhizoctonia solani, Sclerotinia sclerotiorum ve Alternaria alternata'ya karşı antifungal aktivitesi; (i) agar kuyu difüzyonu, (ii) mantar kolonisinin morfolojik çeşitliliği, (iii) hif inhibisyonu ve (iv) minimum inhibisyon konsantrasyonu (MIC) analizleri ile araştırılmıştır. Yaprak özütlerinden türetilen AgNP'ler, kök ve gövde özütlerinden hazırlanan AgNP'lere göre önemli ölçüde yüksek antifungal aktivite sergilemiştir. Ticari AgNP'ler ayrıca bu araştırmada sentezlenen yeşil eşdeğerlerinden daha düşük antifungal aktivite göstermiştir. Ayrıca, sentezlenen AgNP'lerin düşük ( 50 $\mu \mathrm{g} /$ $\mathrm{mL}$ ) konsantrasyonunun bile Fusarium tricinctum ve Colletotrichum sp'nin gelişimini baskılamada etkili olduğu bulunmuştur.

\section{Anahtar Kelimeler}

Phaseolus vulgaris L., yeşil sentez, gümüş nanoparçacık (AgNP), antifungal aktivite. 


\section{INTRODUCTION}

In the last decade, advanced biological techniques based on phyto-nanobiotechnology, including the utilization of herbal extracts, have made significant progress as a sub-branch of nanotechnology [1-3]. The procedures used in this context have mainly a "green" synthesis perspective, thus providing a more efficient and environmentally-friendly approach, saving energy, as well as being more economical when compared to traditional materials $[4,5]$. Researchers are now able to generate end products with pre-designed and diversified functional properties by interpreting nanoparticles, which are at the core of the field of nanotechnology. Therefore, a significant number of researches has been carried out in the literature about "green" synthesis and characterization of the metal nanoparticles, especially for gold $(\mathrm{Au})$, silver $(\mathrm{Ag})$, platinum $(\mathrm{Pt})$, and palladium $(\mathrm{Pd})[6-9]$.

It should also be mentioned that AgNPs prepared by methods based on chemical or phyto-nanobiotechnology have been found extensive use in the fields of biosensor [10-14], photonic [15,16], photocatalysis [17-20], pharmaceutics [21-26], and microelectronics [27-31]. Besides, AgNPs have been shown to have conspicuous antifungal [32-34], antimicrobial [35-39], antiviral [4044], antibacterial [45-49], anti-inflammatory [50-53], and anticancer [54-58] effects. In this scope, soil microorganisms and plant extracts have great potential for the synthesis of target AgNPs as important bioagents [59-63]. Almost all nanobiotechnology applications emphasize the need for new approaches to acquire the resulting nanoparticles through an effective and environmentally friendly synthesis process.

Nowadays, organic and inorganic reducing agents, such as sodium citrate $[64,65]$, sodium ascorbate [66], sodium borohydride [67], and elemental hydrogen [68], are widely used in the synthesis of AgNPs. In general, these reducing agents provide the reduction of positively charged silver (I) ions to the metallic form silver (0). In this study, in contrast to the toxic reducing agents used in chemical methods, extracts from bean plants in the aqueous medium were used. Following this strategy, we have sought to develop an environmentally friendly and inexpensive synthetic approach to obtain target AgNPs. The efficacy of obtaining AgNPs from different parts of Phaseolus vulgaris L. (Yunus-90) was therefore investigated and compared with the activity of synthesized nanoparticles against different fungal plant pathogens.
The methodology used in these experiments is thought to give a unique value to research as it offers a different method to current examples in literature.

\section{MATERIALS and METHODS}

\section{Plant Growth, Sampling and Extraction Procedures}

The seeds (common bean 'Yunus-90 cv.') supplied by the 'Transitional Zone Agricultural Research Institute, Eskişehir, Turkey,' were surface sterilized in hypochlorite solution (5\%, v/v) for $5 \mathrm{~min}$. The sterilized seeds were then hydroponically grown in pots containing modified $1 / 10$ Hoagland solution $(0.2 \mathrm{~L})$ until the plants reach full maturity, also known as the trifoliate leaf stage. Following this step, the root, stem, and leaf tissues considered for AgNPs synthesis were harvested [69]. Each tissue sample ( $200 \mathrm{~g}$ ) was washed with the ddH2O three times and boiled in $\mathrm{ddH}_{2} \mathrm{O}(200 \mathrm{~mL})$. The extracts were incubated at $60^{\circ} \mathrm{C}$ for one hour in a water bath. Upon incubation, plant extracts were filtered using Whatman filter paper (No: 1), and the final extracts were held at $-20^{\circ} \mathrm{C}$ during the investigation (Fig S1).

\section{Preparation of the Silver Nanoparticles}

Plant extract $(10 \mathrm{~mL})$ was allowed to warm up to room temperature (RT) to prepare AgNPs. The extract was then combined with $\mathrm{AgNO} 3(1 \mathrm{mM}, 100 \mathrm{~mL}$ ) and agitated for an additional $45 \mathrm{~min}$ at RT. The resultant mixture was centrifuged at 10,000 rpm for $30 \mathrm{~min}$ to precipitate the intended AgNPs (Fig. S2). The collected nanoparticles were transferred to the microfuge tubes $(1.5 \mathrm{~mL})$ and washed three times with $\mathrm{ddH} 2 \mathrm{O}$. After drying in the oven at $65^{\circ} \mathrm{C}$, the concentration of AgNP obtained was determined (approximately 1.8 to $2.5 \mathrm{mg}$ per milliliter of leaf extract).

\section{Structural Characterization of the Silver Nanoparticles}

The target AgNPs obtained from the leaf, stem, and root extracts were firstly characterized by using Ultravioletvisible spectroscopy (UV-vis), and Fourier Transform Infrared Spectroscopy (FT-IR) techniques. The AgNPs obtained from the leaf extracts were also investigated by Transmission Electron Microscopy (SEM), Scanning Electron Microscopy (SEM) and Dynamic Light Scattering Spectroscopy (DLS) techniques. In this scope, UVvis spectra were taken using a Cary 100 Scan UV-vis spectrophotometer (Varian, Germany) in quartz cuvet- 
tes $(3,500 \mu \mathrm{L}, 10 \mathrm{~mm}$ light path, Hellma 110-QS) at a scanning rate of $1 \mathrm{~nm}$ at a range of 300-800 nm. While UV-vis spectra were taken, $\mathrm{ddH} 2 \mathrm{O}$ was used as a solvent to show consistency with the experimental conditions. Perkin Elmer Spectrum 100 FT-IR spectrometer (Perkin-Elmer Inc., Norwalk, CT, USA) was used to obtain the corresponding FT-IR spectra by applying the ATR kit. The surface morphology of AgNPs was performed by using an FEl, Tecnai G2 F30 (LaB6 type electron gun, 20x-910.000x magnification axis, $0.2 \pm 0.04 \mathrm{~nm}$ point resolution power) (Thermo Fisher Scientific, Hillsboro, OR, USA) microscope (TEM) and a Zeiss EVO-40 Model (500V-30kV High Voltage; SE, BSD, EDX, VPSE detector, W-filament electron gun) (Carl Zeiss, Oberkochen, Germany) electron microscope (SEM), respectively. Malvern ZetaSizer NanoZS90 (Malvern instruments Ltd., UK) was also used for the size analysis of the AgNPs at $25^{\circ} \mathrm{C}$ for a measurement period of 20 seconds.

\section{Antifungal Activity Studies \\ Fungal cultures}

Colletotrichum sp., Fusarium oxysporum, Fusarium acuminatum, Fusarium tricinctum, Fusarium graminearum, Fusarium incarnatum, Rhizoctonia solani, Sclerotinia sclerotiorum, and Alternaria alternata fungal pathogen isolates which were known to cause pathogenic effects in common bean were obtained from Ankara University, Biotechnology Institute. Potato Dextrose Agar (PDA; Merck, Darmstadt, Germany) was used to prepare corresponding active cultures. Fungal colonies were inoculated on PDA plates, and Petri dishes were incubated at $25^{\circ} \mathrm{C}$ for 24 to $48 \mathrm{~h}$, and the growth of isolates was monitored at regular intervals. Active fungal cultures were maintained for use in subsequent studies.

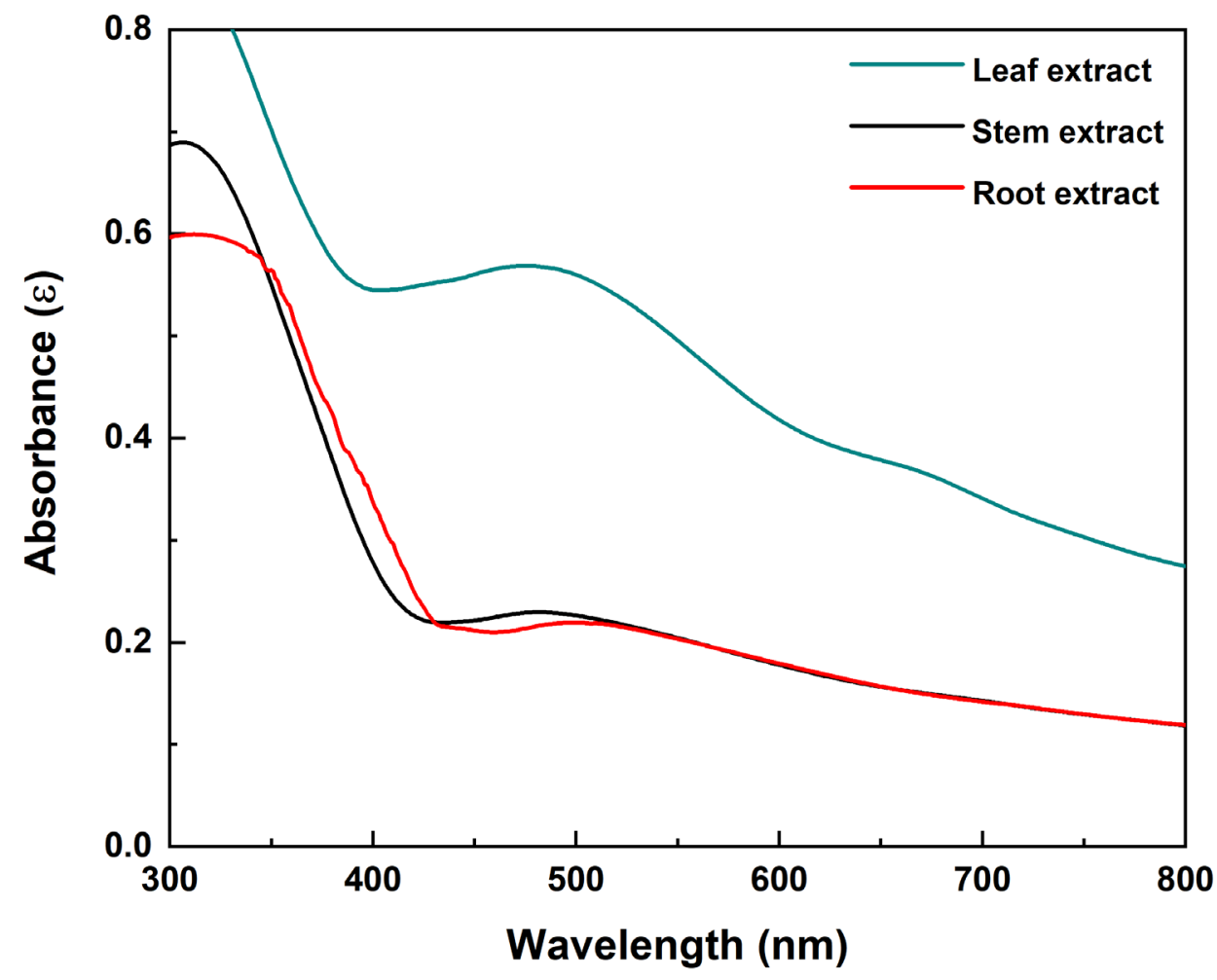

Figure 1. The UV-vis spectra of the AgNPs synthesized by using Phaseolus vulgaris L. leaf, stem, and root extracts. 


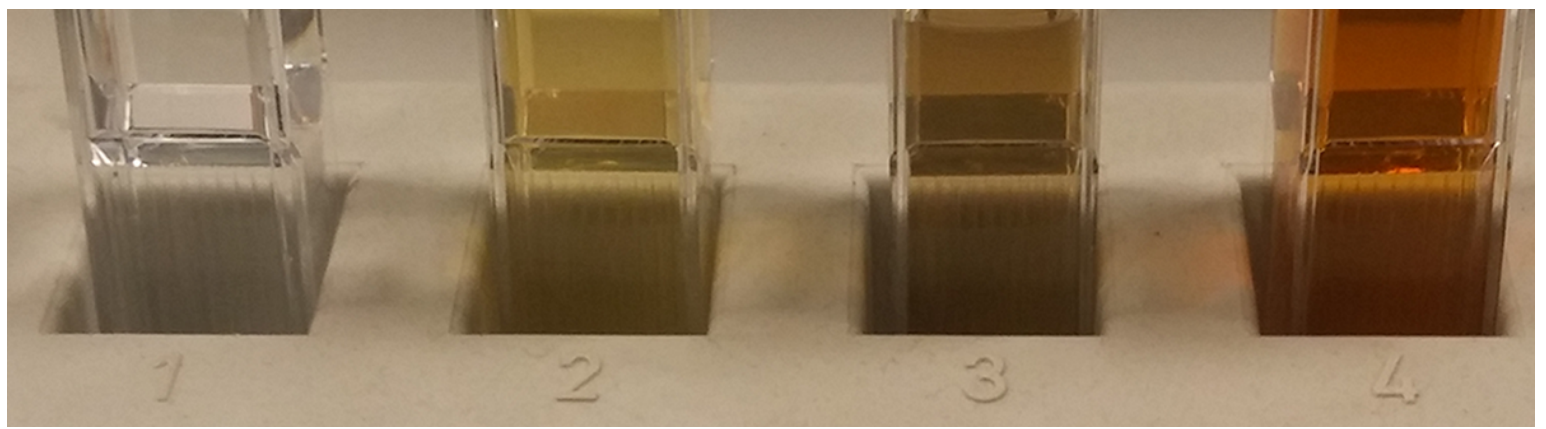

Figure 2. Time-dependent formation of the AgNPs in Phaseolus vulgaris L. leaf extracts.

\section{Determination of antimicrobial activity by agar well diffusion method}

According to a previous study, the antimicrobial effect of AgNPs on fungal pathogens was measured by the implementation of a typical agar well diffusion technique [70]. Consequently, the antimicrobial activity of the synthesized AgNPs utilizing different parts of the common bean (root, stem and leaf) has been thoroughly investigated. To this purpose, active fungal colonies were harvested by sterile loops, and the samples were transferred to the tubes containing $5 \mathrm{~mL}$ of sterile saline $(0.85 \% \mathrm{NaCl})$. The suspensions were prepared based on the 0.5 MacFarland standard. Subsequently, $100 \mathrm{uL}$ of these samples were taken and inoculated into the tubes comprising $5 \mathrm{~mL}$ of soft PD (0.75\% agar) and vortexed. After this phase, soft media spread to the surfaces of the PDA-containing Petri dishes. The Petri dishes were allowed to dry for $10 \mathrm{~min}$ before treatment. $9 \mathrm{~mm}$ wells were drilled on the agar surfaces under aseptic conditions. $100 \mathrm{uL}$ of AgNPs prepared from root, stem, and leaves and adjusted to $1 \mathrm{mg} / \mathrm{mL}$ concentration were transferred into the wells. Petri dishes were finally incubated at $25^{\circ} \mathrm{C}$ for $24 \mathrm{~h}$. After the incubation, inhibition zone diameters were measured in " $\mathrm{mm}$ " and the resulting antimicrobial activity was then determined.

\section{Determination of inhibition in the development of the fungal colony}

AgNPs prepared from the plant leaves were added to the prepared PD agar $(20 \mathrm{~mL})$ with an increasing concentration of $0.125,0.25,0.5,1,2$ and $4 \mathrm{mg} / \mathrm{mL}$ before dispensing to the Petri dishes. The media containing the required concentration of AgNPs were then poured into the Petri dishes and allowed to dry. In this study, the susceptible fungal isolates inhibited by synthesized AgNPs (Fusarium oxysporum, Fusarium graminearum, Fusarium incarnatum, Fusarium acuminatum, Fusarium tricinctum, Colletotrichum sp.) were used. The culture of inoculation has been developed, as already mentioned. Active crops have been found at the core of the PDA dishes containing different concentrations of AgNPs. Particle-free PDA media have been used as a positive control group and all Petri dishes were incubated at $25^{\circ} \mathrm{C}$ for 24 to $48 \mathrm{~h}$. The diameters of the colonies were measured in $\mathrm{mm}$. The percentages of declines in the growth of the colony were calculated based on the growth of the colony in the positive control groups [71].

\section{Microscopic analysis of regression in hyphae development}

The preparation of fungal samples from test groups with the highest particle concentration and control groups was carried out by microscopic sliding. The samples were stained with methylene blue and examined at 40X and 100X magnifications under a light field microscope (Leica, Germany).

\section{Minimum inhibition concentration (MIC) tests}

In this research, the susceptible fungal isolates to AgNPs are favored throughout accordance with previous antifungal activity studies. The cultivation of fungal isolates was carried out in YPG medium (Yeast-Peptone-Glucose; Yeast extract $10 \mathrm{~g} / \mathrm{L}$, Peptone $20 \mathrm{~g} / \mathrm{L}$, Glucose $20 \mathrm{~g} / \mathrm{L}$ ). The appropriate incubation times were considered for each isolate at $25^{\circ} \mathrm{C}$ for the growth of cultures (in the case of Fusarium graminearum, Fusarium incarnatum, Fusarium acuminatum, Fusarium oxysporum; 48 h, for Fusarium tricintum and Colletotrichum sp; 96 h). The activated cultures were then used for MIC test. In this assay, the antifungal activity of AgNPs obtained through green synthesis from plant leaves and commercially available AgNPs (Merck, Product Code: 730785, Germany). The culture suspensions containing both green and chemically synthesized AgNPs adjusted to final (0.0, $0.312,0.625,1.25,2.5$, and $5.0 \mathrm{mg} / \mathrm{mL}$ ) concentrations by sequential dilution using YPG medium $(100 \mu \mathrm{L})$ in 


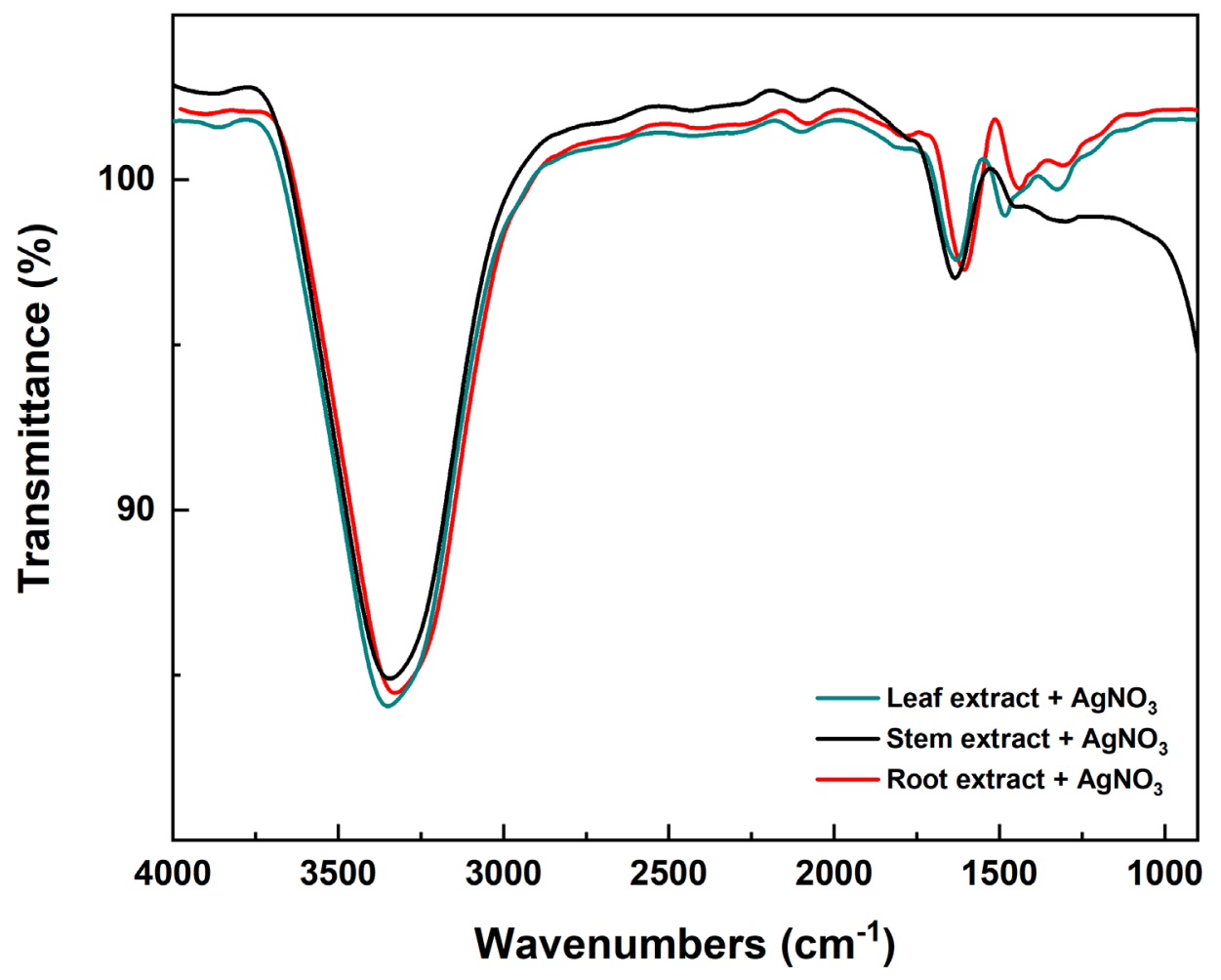

Figure 3. FT-IR spectra of leaf, stem, and root extracts containing AgNPs .

U-bottom 96-well microtiter plate wells. Only inoculum-containing wells were used as positive controls without AgNPs, while only medium-containing wells were designed as negative wells. The activated fungal cultures were vortexed at the highest intensity before inoculation, and $10 \mu \mathrm{L}$ of the culture suspensions were inoculated into the test and positive control wells. Plates were incubated at $25^{\circ} \mathrm{C}$ for 48 and $96 \mathrm{~h}$. At the end of the incubation periods, the culture suspensions in the wells were suspended by pipetting and $50 \mu \mathrm{L}$ these suspensions were transferred and spotted onto PDA plates by drop plate method. Petri dishes were allowed to incubate at $25^{\circ} \mathrm{C}$ for $48 \mathrm{~h}$, and the concentrations that completely inhibited the fungal growth were determined to be MIC values at the end of the incubation [72].

\section{RESULTS and DISCUSSION}

The synthesis of AgNPs from plant extracts was carried out using a phyto-nanotechnological process. The average amount of nanoparticles per milliliter of leaf ext- ract ranged from $1.8 \mathrm{mg}$ to $2.5 \mathrm{mg}$. On the other hand, the extracted nanoparticle mass per milliliter of stem and root extract was estimated to be $0.8 \mathrm{mg}$ and 0.3 $\mathrm{mg}$, respectively. UV-vis spectroscopy was used for the structural analysis of the nanoparticles, and according to the results, in the natural bio-reducing extract medium of Phaseolus vulgaris L., silver (I) cations were reduced to neutral silver (0) and, eventually AgNPs were produced. As shown in Figure 1, the broadband observed in the 450-480 $\mathrm{nm}$ range, especially in leaf extract, is characteristic for polydispersed AgNPs in solution. Similar band formation can be identified for stem extract even if it is weak; however, no substantial band formation is observed in root extract in this region (Figure 1).

According to previous literature research, AgNPs, whose concentration of the solution increases over time, can be qualitatively observed by taking a yellow-brown color in their solutions due to vibration motions according to the theory known as surface plasmon resonance [73-75]. The surface plasmon resonance is a physical 
phenomenon that arises as a result of the vibration motions of the plane-polarized light on the metal surface during its reflection. In general, color changes were observed with the application of silver nitrate solution to the colorless plant extracts, which initially approached yellow and then became brown in this analysis (Figure 2, Fig S3).

A

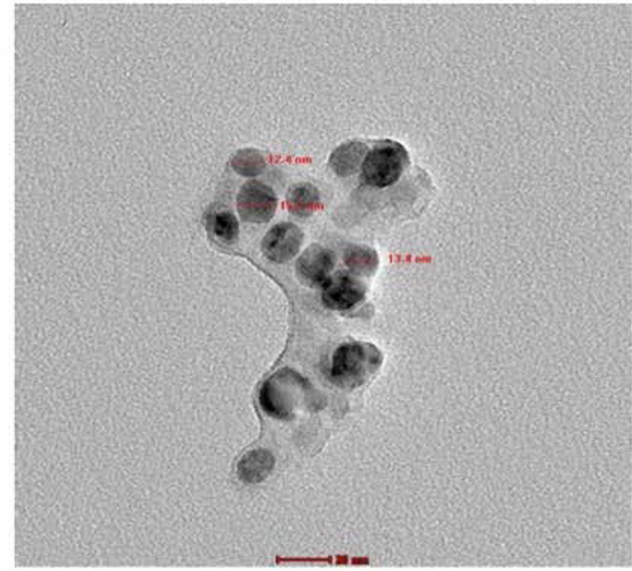

B

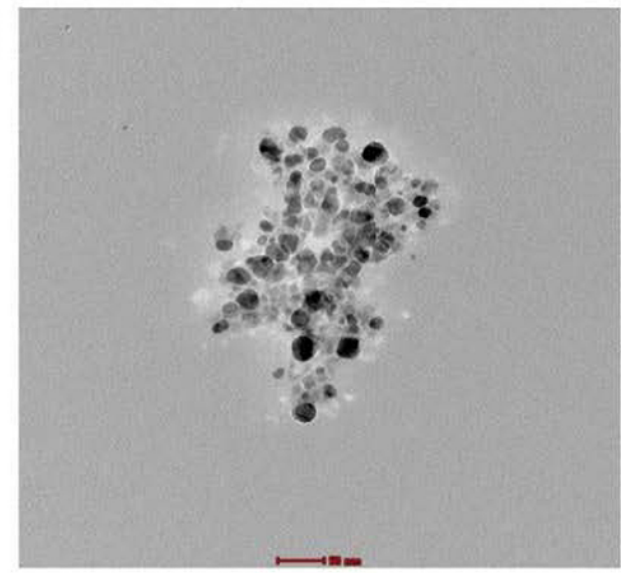

C

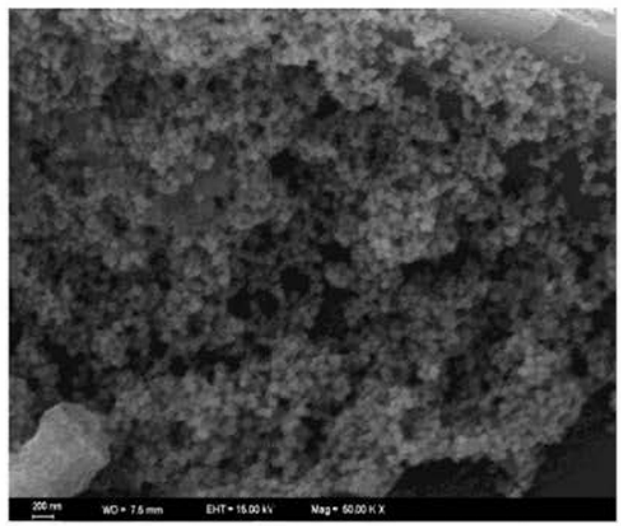

Plant extracts constitute a rich environment of amino acids and proteins. The carbonyl groups of these complex molecules surround AgNPs and enhance particle stability. Once their environmental stability has been enhanced, the possible agglomeration is avoided, and the growth of particle size is also inhibited. According to this observation, leaf, root, and stem extracts have, according to the FT-IR study, also been shown to consist of similar functional groups (Figure 3).

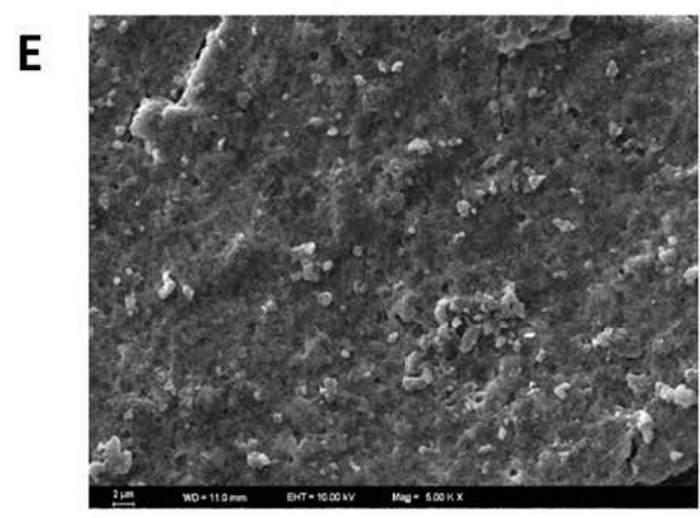

Figure 4. $\operatorname{TEM}(A, B)$ and $S E M(C, D, E)$ images of the AgNPs in leaf extracts. 


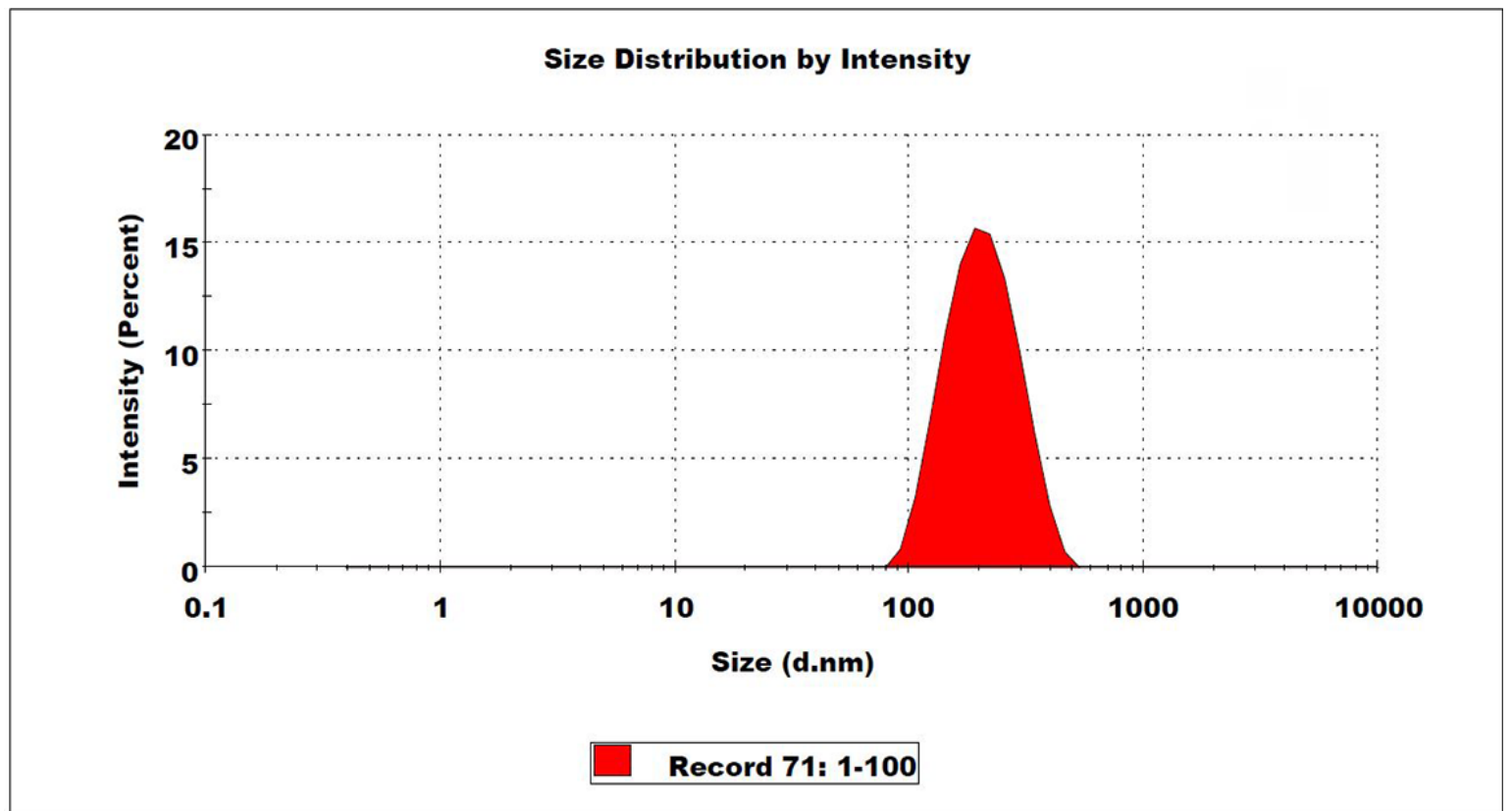

Figure 5. DLS analysis of the AgNPs obtained from leaf extract.

In the FT-IR spectrum, the strong and broadband in the range of 3500 to $3200 \mathrm{~cm}^{-1}$ belongs to the $\mathrm{O}-\mathrm{H}$ stretch, which is typically observed in phenols and hydrogenbonded alcohols. The weak peak observed at $2086 \mathrm{~cm}^{-1}$ corresponds to the aromatic C-O stretch of the polyol groups. The relatively sharp peak at $1636 \mathrm{~cm}^{-1}$ shows off-plane bending vibrations in substituted ethylene systems. As mentioned before, the carbonyl $(C=O)$ functional group and the hydroxyl $(\mathrm{OH})$ groups formed in the structure of the plant extract and the reduction of this group have the potential to bond firmly by interacting with metal nanoparticles. In other words, AgNPs are surrounded by these biostructures like a capsule, thus reducing the potential of metal particles to come together to form agglomeration, increasing the stability of the solution medium [53].

TEM images from the leaf (Figure 4), stem and root (Fig S4) extracts particles show that the synthesized AgNPs have a very smooth surface morphology and spherical geometry. The nanoparticles were found to have an average diameter of 12 to $16 \mathrm{~nm}$ with highly uniformly dispersed, as shown in the TEM images. This leads to the conclusion that some essential bioorganic molecules in the plant extract behave as a ligand that stabilizes the AgNPs in the medium. In other words, the compo- nents in the plant control the growth and aggregation kinetics of the nanoparticles.

Finally, the DLS technique was used for the structural characterization of nanoparticles, and particle size distributions in extracts were examined. Measurements, where the average particle size is estimated to be 188 $\mathrm{nm}$, confirming that AgNPs are present in small clusters and do not contain agglomerates (Figure 5).

\section{Antifungal Activity}

The antifungal effects of AgNPs from different parts of the common bean were measured using the technique of well diffusion agar as shown in Table 1.

It was concluded that the AgNPs obtained from leaf extracts demonstrated higher levels of antifungal activity than nanoparticles derived from the root and stem extracts. After applying nanoparticles to leaf extracts, most of the wells observed the development of an inhibition zone. Nonetheless, after treatment with root and stem extracts, almost no inhibition zone formation was observed (Table 1). The formed inhibition zone images were also provided in Table 2. 
Table 1. Evaluation of the antifungal activity of silver nanoparticles.

\begin{tabular}{cccc}
\hline Species Name & Leaf & Stem & Root \\
\hline Fusarium acuminatum & $14 \mathrm{~mm}$ & $11 \mathrm{~mm}$ & - \\
\hline Fusarium incarnatum & $18 \mathrm{~mm}$ & - & - \\
\hline Fusarium graminearum & $12 \mathrm{~mm}$ & - & - \\
\hline Fusarium tricinctum & $15 \mathrm{~mm}$ & - & - \\
\hline Fusarium oxysporum & $13 \mathrm{~mm}$ & - & - \\
\hline Rhizoctonia solani & - & - & - \\
\hline Sclerotinia sclerotiorum & - & - & - \\
\hline Colletotrichum $\mathrm{sp}$. & $18 \mathrm{~mm}$ & - & - \\
\hline Alternaria alternata & - & & \\
\hline
\end{tabular}

Through doing this, the zone diameters of the corresponding fungal species were determined to assess the inhibition of the growth of the fungal colony. As a result, the growth of fungal pathogens was reduced at higher concentrations of AgNPs. As shown in Table 3, the development of Fusarium tricinctum and Colletotrichum sp. species was inhibited. On the other hand, when compared with the control group, the most of the fungal species were shown to have decreased zone diameters with increased concentrations of AgNPs (Table 3).
The zone diameters of fungal pathogens exposed to different concentrations of nanoparticles have been measured, and their developmental tendencies have been determined. Table 4 indicates the concentrationdependent shifts (\%) in the diameter of the zone.

Table 2. Inhibition zone formation by agar well diffusion assay (Y: leaf, G: stem, K: root extracts)

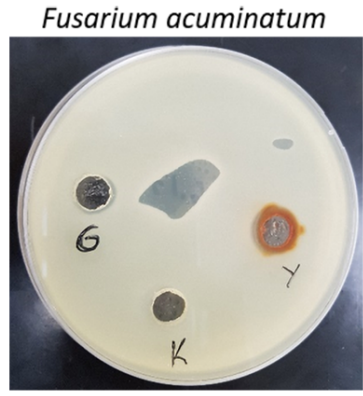

Fusarium tricinctum

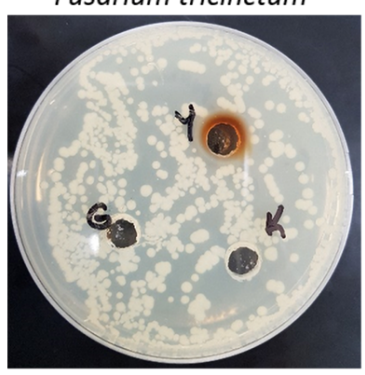

Fusarium incarnatum

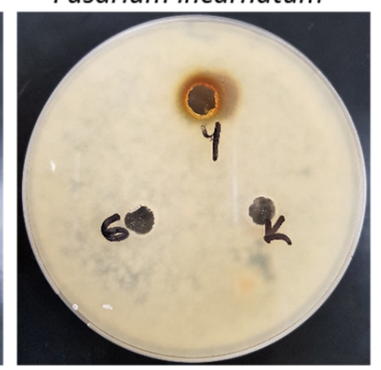

Fusarium oxysporum

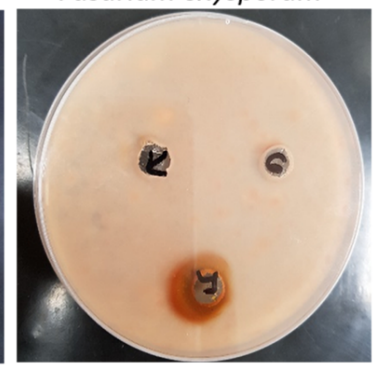

Fusarium graminearum

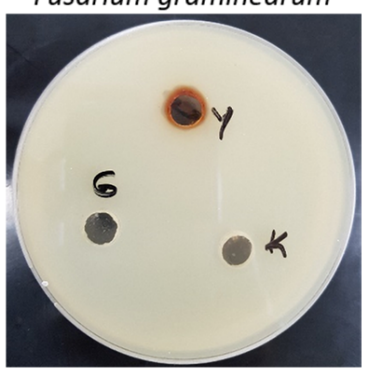

Colletotrichum $s p$.

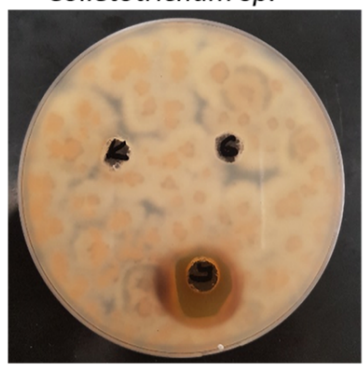

$1 \mathrm{~cm}$ 
Table 3.Comparison of the development of fungal colonies in medium containing a high concentration of AgNPs (right) and the control group (left).
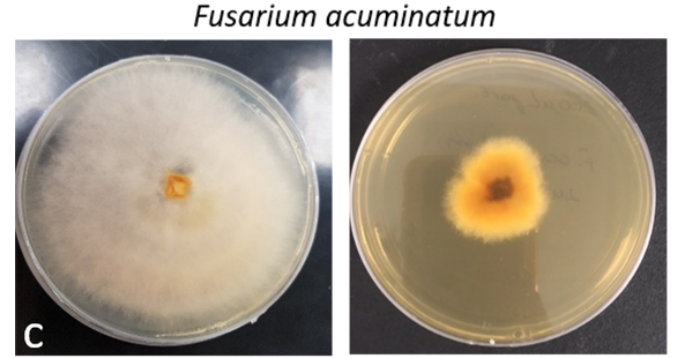

Fusarium graminearum
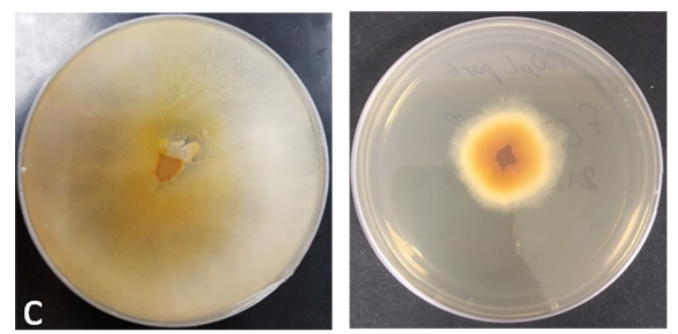

Fusarium oxysporum
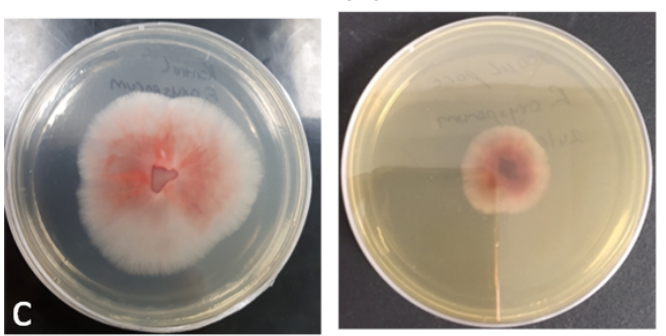

Fusarium incarnatum

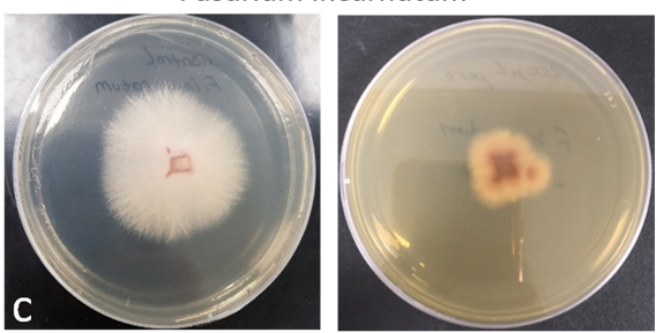

Fusarium tricinctum

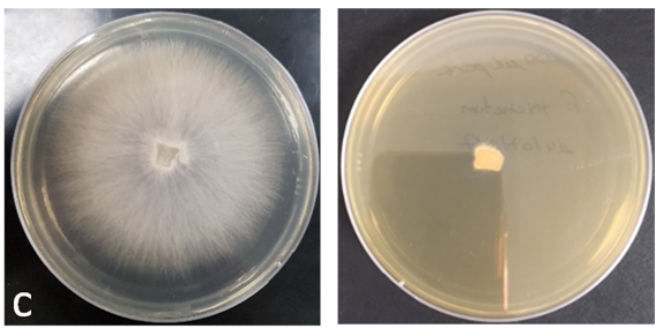

Colletotrichum sp.
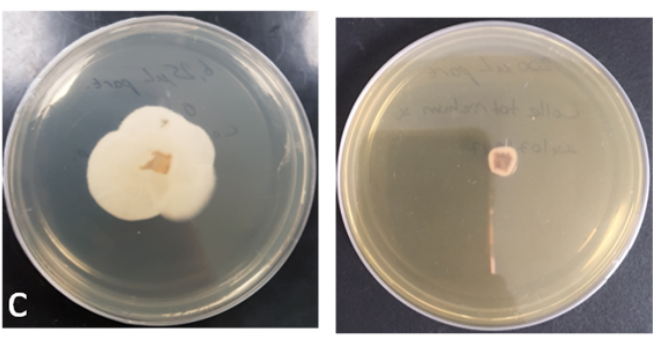

$1 \mathrm{~cm}$

Table 4. The regression in colony diameters of fungal species with an increased concentration of AgNPs.

\begin{tabular}{|c|c|c|c|c|c|c|}
\hline AgNP concentration & $\begin{array}{c}6.25 \\
\mu \mathrm{g} / \mathrm{mL}\end{array}$ & $\begin{array}{l}12.50 \\
\mu \mathrm{g} / \mathrm{mL}\end{array}$ & $\begin{array}{l}25.00 \\
\mu \mathrm{g} / \mathrm{mL}\end{array}$ & $\begin{array}{l}50.00 \\
\mu \mathrm{g} / \mathrm{mL}\end{array}$ & $\begin{array}{l}100.00 \\
\mu \mathrm{g} / \mathrm{mL}\end{array}$ & $\begin{array}{l}200.00 \\
\mu \mathrm{g} / \mathrm{mL}\end{array}$ \\
\hline Fungal species & \multicolumn{6}{|c|}{ Colony regression (mm; \%) } \\
\hline Fusarium acumitnatum & $\begin{array}{l}3 \mathrm{~mm} ; \\
3.90 \%\end{array}$ & $\begin{array}{l}3 \mathrm{~mm} ; \\
3.90 \%\end{array}$ & $\begin{array}{l}6 \mathrm{~mm} \\
7.79 \%\end{array}$ & $\begin{array}{l}23 \text { mm; } \\
29.87 \%\end{array}$ & $\begin{array}{c}46 \mathrm{~mm} \\
59.74 \%\end{array}$ & $\begin{array}{l}49 \mathrm{~mm} ; \\
63.63 \%\end{array}$ \\
\hline Fusarium incarnatum & $\begin{array}{c}4 \mathrm{~mm} \\
10.53 \%\end{array}$ & $\begin{array}{l}4 \mathrm{~mm} ; \\
10.53 \%\end{array}$ & $\begin{array}{l}4 \mathrm{~mm} \\
10.53 \%\end{array}$ & $\begin{array}{l}5 \mathrm{~mm} \\
13.16 \%\end{array}$ & $\begin{array}{l}18 \mathrm{~mm} ; \\
47.37 \%\end{array}$ & $\begin{array}{l}18 \mathrm{~mm} ; \\
47.37 \%\end{array}$ \\
\hline Fusarium graminearum & $\begin{array}{c}0 \mathrm{~mm} \\
0 \%\end{array}$ & $\begin{array}{c}0 \mathrm{~mm} \\
0 \%\end{array}$ & $\begin{array}{c}0 \mathrm{~mm} \\
0 \%\end{array}$ & $\begin{array}{c}0 \mathrm{~mm} \\
0 \%\end{array}$ & $\begin{array}{l}48 \mathrm{~mm} ; \\
60.76 \%\end{array}$ & $\begin{array}{l}58 \mathrm{~mm} ; \\
73.42 \%\end{array}$ \\
\hline Fusarium tricinctum & $\begin{array}{l}20 \mathrm{~mm} ; \\
30.77 \%\end{array}$ & $\begin{array}{l}29 \mathrm{~mm} ; \\
44.61 \%\end{array}$ & $\begin{array}{l}46 \mathrm{~mm} ; \\
70.76 \%\end{array}$ & $\begin{array}{l}58 \mathrm{~mm} \\
89.23 \%\end{array}$ & $\begin{array}{l}60 \mathrm{~mm} ; \\
92.30 \%\end{array}$ & $\begin{array}{c}65 \mathrm{~mm} ; \\
100 \%\end{array}$ \\
\hline Fusarium oxysporum & $\begin{array}{c}0 \mathrm{~mm} ; \\
0 \%\end{array}$ & $\begin{array}{c}0 \mathrm{~mm} \\
0 \%\end{array}$ & $\begin{array}{c}0 \mathrm{~mm} \\
0 \%\end{array}$ & $\begin{array}{c}2 \mathrm{~mm} ; \\
4 \%\end{array}$ & $\begin{array}{c}25 \mathrm{~mm} \\
50 \%\end{array}$ & $\begin{array}{c}29 \mathrm{~mm} ; \\
58 \%\end{array}$ \\
\hline Colletotrichum sp. & $\begin{array}{c}0 \mathrm{~mm} \\
0 \%\end{array}$ & $\begin{array}{c}0 \mathrm{~mm} \\
0 \%\end{array}$ & $\begin{array}{c}0 \mathrm{~mm} \\
0 \%\end{array}$ & $\begin{array}{c}5 \mathrm{~mm} \\
19.23 \%\end{array}$ & $\begin{array}{l}15 \mathrm{~mm} ; \\
57.69 \%\end{array}$ & $\begin{array}{c}26 \mathrm{~mm} ; \\
100 \%\end{array}$ \\
\hline
\end{tabular}


20 E. Ediz et al. / Hacettepe J. Biol. \& Chem., 2021, 49 (1), 11-23

Table 5. Light microscopy analysis of hyphae in the medium containing a high concentration of AgNPs (right) and the control group (left).
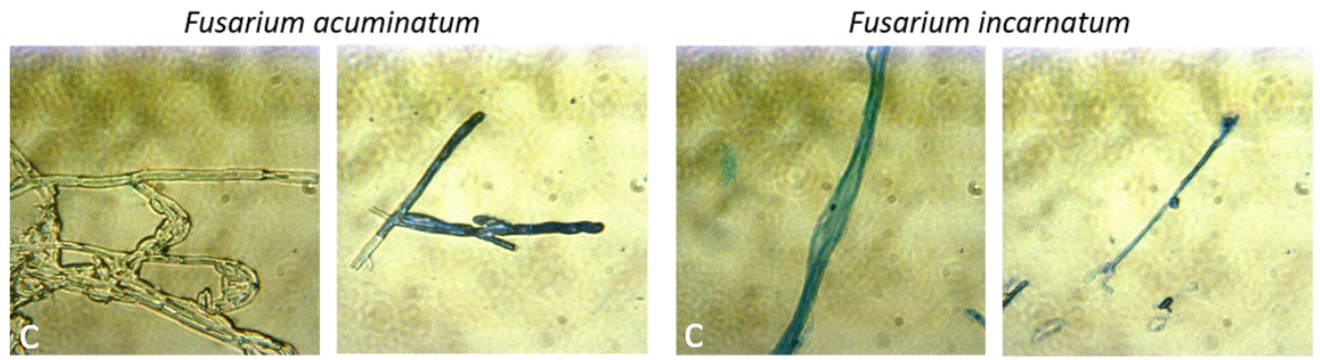

\section{Fusarium graminearum}
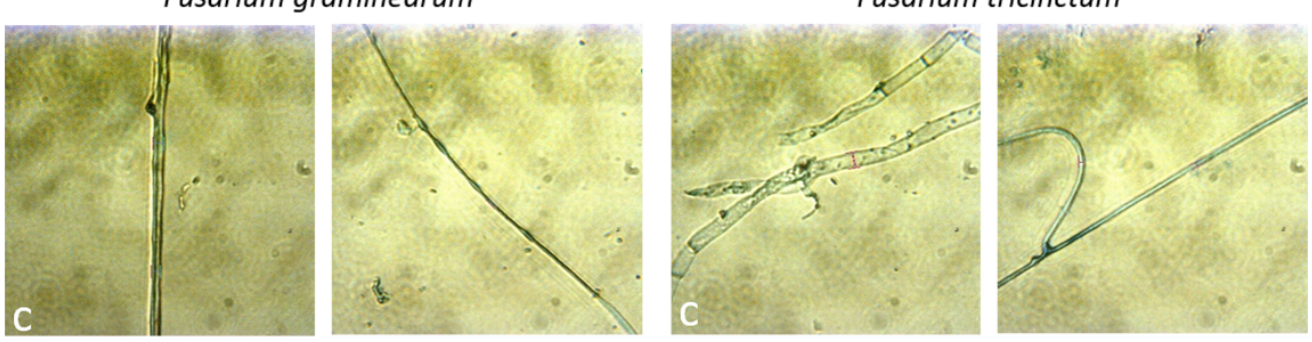

Fusarium oxysporum

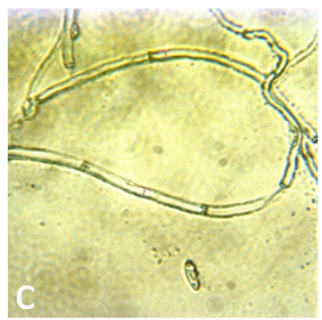

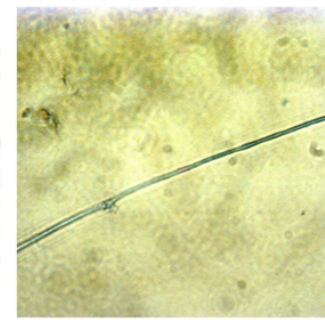

Colletotrichum $s p$.
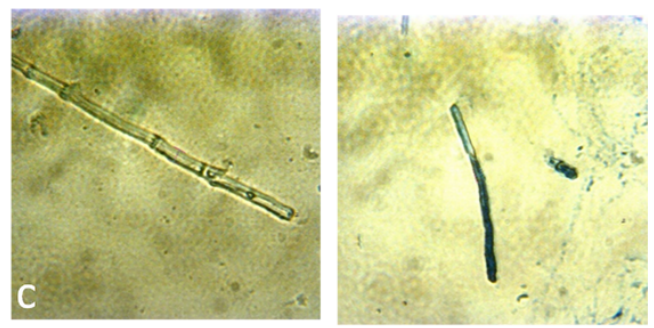

$1 \mathrm{~cm}$

Table 6. Evaluation of the antifungal activity of silver nanoparticles.

\begin{tabular}{ccc}
\hline Fungal Species & $\begin{array}{c}\text { AgNPs } \\
\text { (synthesized in this study }\end{array}$ & $\begin{array}{c}\text { AgNPs } \\
\text { (commercially purchased) }\end{array}$ \\
\hline Fusarium acuminatum & $0.312 \mathrm{mg} / \mathrm{mL} \geq$ & $5.0 \mathrm{mg} / \mathrm{mL}$ \\
\hline Fusarium incarnatum & $0.312 \mathrm{mg} / \mathrm{mL} \geq$ & $1.25 \mathrm{mg} / \mathrm{mL}$ \\
\hline Fusarium graminearum & $1.25 \mathrm{mg} / \mathrm{mL}$ & $1.25 \mathrm{mg} / \mathrm{mL}$ \\
\hline Fusarium tricinctum & $0.312 \mathrm{mg} / \mathrm{mL} \geq$ & $0.312 \mathrm{mg} / \mathrm{mL}$ \\
\hline Fusarium oxysporum & $0.312 \mathrm{mg} / \mathrm{mL} \geq$ & $0.312 \mathrm{mg} / \mathrm{mL}$ \\
\hline Colletotrichum sp. & $0.312 \mathrm{mg} / \mathrm{mL} \geq$ & $0.625 \mathrm{mg} / \mathrm{mL}$ \\
\hline
\end{tabular}


The reduced growth rate observed for the investigated fungal species was associated with the concentration of AgNPs. 100 and $200 \mu \mathrm{g} / \mathrm{mL}$ particle concentrations were shown to slow down the pathogen development in a more effective way than lower concentrations. Surprisingly, this reduction was also valid for lower concentrations ( 25 and $50 \mu \mathrm{g} / \mathrm{mL}$ ) of silver nanoparticles in Fusarium tricintum (Figure 5). Hyphae extracts of fungal pathogen culture collected after $48 \mathrm{~h}$ is treated with methylene blue. Subsequently, the silver nanoparticlecontaining $(200 \mu \mathrm{g} / \mathrm{mL})$ media and control group (without nanoparticles) samples were compared in terms of antifungal impact. Based on these results, the hyphae diameter of all pathogens is significantly increased with an increased concentration of the particle suggesting inhibition of pathogen dissemination (Table 5).

The objective of the MIC analysis was to determine the minimum concentration of particles required to inhibit the growth of pathogenic fungal species. Therefore, a comparable MIC analysis was carried out between the synthesized AgNPs in the current study with the commercially acquired equivalent (Merck, Product Code: 730785, Germany) to shed light on antifungal activity alterations.

Based on the data obtained, the synthesized AgNPs were found to suppress pathogen development except for Fusarium graminearum at lower concentrations than its commercial counterpart (Table 6).

\section{CONCLUSION}

In this study, the target AgNPs have been successfully prepared by using a green, environmentally friendly, cost-effective, and virtually acceptable leaf, stem, and root parts of the common bean. The structural characterization of the synthesized AgNPs was carried out by using appropriate spectral techniques. In the following stage, high anti-fungal activity was found even in low concentrations for the synthesized AgNPs, especially in the case of Fusarium tricinctum. In other words, synthesized AgNPs were shown to have a considerable potential to be used for suppressing several fungal plant pathogens. Besides that, the nanoparticles obtained from leaf extracts were determined to have a more effective antifungal activity than those from root and stem. Therefore, we suggest that the protection of the economically important plants, such as common beans against the specific fungal pathogens, could be performed fol- lowing the marketing of these newly synthesized green AgNPs.

\section{References}

1. P. Wang, E. Lombi, F.J. Zhao, P.M. Kopittke, Nanotechnology: A New Opportunity in Plant Sciences, Trends Plant Sci., 21 (2016) 699-712.

2. T. Khan, P. Gurav, PhytoNanotechnology: Enhancing delivery of plant based anti-cancer drugs, Front. Pharmacol., (2018).

3. P. Mohammadi, M. Hesari, H. Samadian, M. Hajialyani, Z. Bayrami, M.H. Farzaei, M. Abdollahi, Recent advancements and new perspectives of phytonanotechnology, in: Compr. Anal. Chem., 2019

4. P. Agarwal, R. Gupta, N. Agarwal, Advances in Synthesis and Applications of Microalgal Nanoparticles for Wastewater Treatment, J. Nanotechnol., 2019 (2019) 1-9.

5. R. Rajan, K. Chandran, S.L. Harper, S. II Yun, P.T. Kalaichelvan, Plant extract synthesized silver nanoparticles: An ongoing source of novel biocompatible materials, Ind. Crops Prod., 70 (2015) 356-373.

6. H.R. Ghorbani, Green synthesis of gold nanoparticles, Orient. J. Chem., 31 (2015) 303-305.

7. P. Rajoriya, P. Misra, V.K. Singh, P.K. Shukla, P.W. Ramteke, Green Synthesis of Silver Nanoparticles, Biotech Today An Int. J. Biol. Sci., (2017).

8. K.S. Siddiqi, A. Husen, Green Synthesis, Characterization and Uses of Palladium/Platinum Nanoparticles, Nanoscale Res. Lett., (2016).

9. A. Asha, Green Synthesis of Silver Nanoparticle from Different Plants-A Review, Int. J. Pure Appl. Biosci., 4 (2016) 118-124.

10. A.J. Haes, R.P. Van Duyne, A nanoscale optical biosensor: Sensitivity and selectivity of an approach based on the localized surface plasmon resonance spectroscopy of triangular silver nanoparticles, J. Am. Chem. Soc., (2002).

11. L. Sintubin, W. Verstraete, N. Boon, Biologically produced nanosilver: Current state and future perspectives, Biotechnol. Bioeng., (2012).

12. J. Lin, C. He, Y. Zhao, S. Zhang, One-step synthesis of silver nanoparticles/carbon nanotubes/chitosan film and its application in glucose biosensor, Sensors Actuators, B Chem., 137 (2009) 768-773.

13. L. Mahmudin, E. Suharyadi, A.B.S. Utomo, K. Abraha, Optical Properties of Silver Nanoparticles for Surface Plasmon Resonance (SPR)-Based Biosensor Applications, J. Mod. Phys., (2015).

14. X. Ren, X. Meng, D. Chen, F. Tang, J. Jiao, Using silver nanoparticle to enhance current response of biosensor, Biosens. Bioelectron., (2005).

15. K. Ueno, Y. Yokota, S. Juodkazis, V. Mizeikis, H. Misawa, Nano-Structured Materials in Plasmonics and Photonics, Curr. Nanosci., 4 (2008) 232-235.

16. P. Akhter, M. Huang, W. Spratt, N. Kadakia, F. Amir, Tailoring the optical constants in single-crystal silicon with embedded silver nanostructures for advanced silicon photonics applications, J. Appl. Phys., 117 (2015).

17. K. Awazu, M. Fujimaki, C. Rockstuhl, J. Tominaga, H. Murakami, Y. Ohki, N. Yoshida, T. Watanabe, A plasmonic photocatalyst consisting of silver nanoparticles embedded in titanium dioxide, J. Am. Chem. Soc., 130 (2008) 16761680. 
18. S. Sarina, E.R. Waclawik, H. Zhu, Photocatalysis on supported gold and silver nanoparticles under ultraviolet and visible light irradiation, Green Chem., 15 (2013) 1814-1833.

19. E. Grabowska, A. Zaleska, S. Sorgues, M. Kunst, A. Etcheberry C. Colbeau-Justin, H. Remita, Modification of titanium(IV) dioxide with small silver nanoparticles: Application in photocatalysis, J. Phys. Chem. C, 117 (2013) 1955-1962.

20. P.D. Cozzoli, R. Comparelli, E. Fanizza, M.L. Curri, A. Agostiano, D. Laub, Photocatalytic Synthesis of Silver Nanoparticles Stabilized by TiO 2 Nanorods: A Semiconductor/Metal Nanocomposite in Homogeneous Nonpolar Solution, J. Am. Chem. Soc., 126 (2004) 3868-3879.

21. J. Jain, S. Arora, J.M. Rajwade, P. Omray, S. Khandelwal, K.M. Paknikar, Silver nanoparticles in therapeutics: Development of an antimicrobial gel formulation for topical use, in: Mol. Pharm., 2009: pp. 1388-1401.

22. G.D. Mogoşanu, A.M. Grumezescu, C. Bejenaru, L.E. Bejenaru, Polymeric protective agents for nanoparticles in drug delivery and targeting, Int. J. Pharm., 510 (2016) 419-429.

23. M. Rai, A.P. Ingle, P. Paralikar, I. Gupta, S. Medici, C.A Santos, Recent advances in use of silver nanoparticles as antimalarial agents, Int. J. Pharm., 526 (2017) 254-270.

24. N. Lochner, C. Lobmaier, M. Wirth, A. Leitner, F. Pittner, F. Gabor, Silver nanoparticle enhanced immunoassays: One step real time kinetic assay for insulin in serum, Eur. J. Pharm. Biopharm., 56 (2003) 469-477.

25. L. Pindáková, V. Kašpárková, K. Kejlová, M. Dvořáková, D. Krsek, D. Jírová, L. Kašparová, Behaviour of silver nanoparticles in simulated saliva and gastrointestinal fluids, Int. J. Pharm., 527 (2017) 12-20

26. K. Kejlová, V. Kašpárková, D. Krsek, D. Jírová, H. Kolářová, M. Dvořáková, K. Tománková, V. Mikulcová, Characteristics of silver nanoparticles in vehicles for biological applications, Int. J. Pharm., 496 (2015) 878-885.

27. M. Torres-Cisneros, C. Velásquez-Ordónez, J. SánchezMondragón, A. Campero, O.G. Ibarra-Manzano, D.A May-Arrioja, H. Plascencia-Mora, A. Espinoza-Calderón, I. Sukhoivanov, Synthesis and optical characterization of Ag0 nanoparticles, Microelectronics J., 40 (2009) 618-620.

28. H.A. Alarifi, M. Atis, C. Özdoğan, A. Hu, M. Yavuz, Y. Zhou, Molecular dynamics simulation of sintering and surface premelting of silver nanoparticles, Mater. Trans., 54 (2013) 884-889.

29. M. Torres-Cisneros, N. Yanagihara, B. Gonzalez-Rolon, M.A. Meneses-Nava, O.G. Ibarra-Manzano, D.A. May-Arrioja, J. Sánchez-Mondragón, E. Aguilera-Gómez, L.A. AguileraCortés, Synthesis and nonlinear optical behavior of $\mathrm{Ag}$ nanoparticles in PMMA, Microelectronics J., 40 (2009) 621-623.

30. S. Thakur, K.M. G., S.R. M., Plant-Mediated Synthesis of Silver Nanoparticles - A Critical Review, Int. J. Pharmacogn. Phytochem. Res., 9 (2018)

31. M. Nakamoto, M. Yamamoto, Y. Kashiwagi, H. Kakiuchi, T. Tsujimoto, Y. Yoshida, A variety of silver nanoparticle pastes for fine electronic circuit pattern formation, in: 6th Int. IEEE Conf. Polym. Adhes. Microelectron. Photonics, Polytronic 2007, Proc., 2007: pp. 105-109.

32. A. Panáček, M. Kolář, R. Večeřová, R. Prucek, J. Soukupová V. Kryštof, P. Hamal, R. Zbořil, L. Kvítek, Antifungal activity of silver nanoparticles against Candida spp, Biomaterials, 30 (2009) 6333-6340.
33. J. Lee, K.-J. Kim, W. Sang, J. Guk, D. Gun, The Silver Nanoparticle (Nano-Ag): a New Model for Antifungal Agents, in: Silver Nanoparticles, 2010

34. Y.K. Jo, B.H. Kim, G. Jung, Antifungal activity of silver ions and nanoparticles on phytopathogenic fungi, Plant Dis., 93 (2009) 1037-1043.

35. J.S. Kim, E. Kuk, K.N. Yu, J.H. Kim, S.J. Park, H.J. Lee, S.H. Kim, Y.K. Park, Y.H. Park, C.Y. Hwang, Y.K. Kim, Y.S. Lee, D.H. Jeong, M.H. Cho, Antimicrobial effects of silver nanoparticles, Nanomedicine Nanotechnology, Biol. Med., 3 (2007) 95-101.

36. M. Rai, A. Yadav, A. Gade, Silver nanoparticles as a new generation of antimicrobials, Biotechnol. Adv., 27 (2009) 76-83.

37. N. Durán, M. Durán, M.B. de Jesus, A.B. Seabra, W.J. Fávaro, G. Nakazato, Silver nanoparticles: A new view on mechanistic aspects on antimicrobial activity, Nanomedicine Nanotechnology, Biol. Med., 12 (2016) 789-799.

38. V.K. Sharma, R.A. Yngard, Y. Lin, Silver nanoparticles: Green synthesis and their antimicrobial activities, Adv. Colloid Interface Sci., 145 (2009) 83-96.

39. I. Sondi, B. Salopek-Sondi, Silver nanoparticles as antimicrobial agent: A case study on $E$ coli as a model for Gram-negative bacteria, J. Colloid Interface Sci., 275 (2004) 177-182.

40. S. Galdiero, A. Falanga, M. Vitiello, M. Cantisani, V. Marra, M. Galdiero, Silver nanoparticles as potential antiviral agents, Molecules, 16 (2011) 8894-8918.

41. H.H. Lara, E.N. Garza-Treviño, L. Ixtepan-Turrent, D.K. Singh, Silver nanoparticles are broad-spectrum bactericidal and virucidal compounds, J. Nanobiotechnology, 9 (2011).

42. H.H. Lara, N. V. Ayala-Nuñez, L. Ixtepan-Turrent, C. Rodriguez-Padilla, Mode of antiviral action of silver nanoparticles against HIV-1, J. Nanobiotechnology, 8 (2010).

43. S.J. Park, H.H. Park, S.Y. Kim, S.J. Kim, K. Woo, G.P. Ko, Antiviral properties of silver nanoparticles on a magnetic hybrid colloid, Appl. Environ. Microbiol., 80 (2014) 23432350.

44. P. Orlowski, E. Tomaszewska, M. Gniadek, P. Baska, J. Nowakowska, J. Sokolowska, Z. Nowak, M. Donten, G. Celichowski, J. Grobelny, M. Krzyzowska, Tannic acid modified silver nanoparticles show antiviral activity in herpes simplex virus type 2 infection, PLoS One, 9 (2014).

45. C.-N. Lok, C.-M. Ho, R. Chen, Q.-Y. He, W.-Y. Yu, H. Sun, P.K.-H. Tam, J.-F. Chiu, C.-M. Che, Silver nanoparticles: partial oxidation and antibacterial activities, JBIC J. Biol. Inorg. Chem., 12 (2007) 527-534.

46. J.R. Morones, J.L. Elechiguerra, A. Camacho, K. Holt, J.B. Kouri, J.T. Ramírez, M.J. Yacaman, The bactericidal effect of silver nanoparticles, Nanotechnology, 16 (2005) 2346-2353.

47. G. Franci, A. Falanga, S. Galdiero, L. Palomba, M. Rai, G. Morelli, M. Galdiero, Silver nanoparticles as potential antibacterial agents, Molecules, 20 (2015) 8856-8874.

48. P. Van Dong, C.H. Ha, L.T. Binh, J. Kasbohm, Chemical synthesis and antibacterial activity of novel-shaped silver nanoparticles, Int. Nano Lett., 2 (2012).

49. B. Le Ouay, F. Stellacci, Antibacterial activity of silver nanoparticles: A surface science insight, Nano Today, 10 (2015) 339-354.

50. S. Gurunathan, K.J. Lee, K. Kalishwaralal, S. Sheikpranbabu, R. Vaidyanathan, S.H. Eom, Antiangiogenic properties of silver nanoparticles, Biomaterials, 30 (2009) 6341-6350. 
51. K.K.Y. Wong, S.O.F. Cheung, L. Huang, J. Niu, C. Tao, C.M. Ho, C.M. Che, P.K.H. Tam, Further evidence of the anti-inflammatory effects of silver nanoparticles, ChemMedChem, 4 (2009) 1129-1135.

52. L. David, B. Moldovan, A. Vulcu, L. Olenic, M. PerdeSchrepler, E. Fischer-Fodor, A. Florea, M. Crisan, I. Chiorean, S. Clichici, G.A. Filip, Green synthesis, characterization and anti-inflammatory activity of silver nanoparticles using European black elderberry fruits extract, Colloids Surfaces B Biointerfaces, 122 (2014) 767-777.

53. H. Mohamed El-Rafie, M. Abdel-Aziz Hamed, Antioxidant and anti-inflammatory activities of silver nanoparticles biosynthesized from aqueous leaves extracts of four Terminalia species, Adv. Nat. Sci. Nanosci. Nanotechnol., 5 (2014).

54. R. Sankar, A. Karthik, A. Prabu, S. Karthik, K.S. Shivashangari, V. Ravikumar, Origanum vulgare mediated biosynthesis of silver nanoparticles for its antibacterial and anticancer activity, Colloids Surfaces B Biointerfaces, 108 (2013) 80-84.

55. M. Rai, K. Kon, A. Ingle, N. Duran, S. Galdiero, M. Galdiero, Broad-spectrum bioactivities of silver nanoparticles: The emerging trends and future prospects, Appl. Microbiol. Biotechnol., 98 (2014) 1951-1961.

56. D. Nayak, S. Pradhan, S. Ashe, P.R. Rauta, B. Nayak, Biologically synthesised silver nanoparticles from three diverse family of plant extracts and their anticancer activity against epidermoid A431 carcinoma, J. Colloid Interface Sci., 457 (2015) 329-338.

57. H. Sharma, P.K. Mishra, S. Talegaonkar, B. Vaidya, Metal nanoparticles: A theranostic nanotool against cancer, Drug Discov. Today, 20 (2015) 1143-1151.

58. V. Kathiravan, S. Ravi, S. Ashokkumar, Synthesis of silver nanoparticles from Melia dubia leaf extract and their in vitro anticancer activity, Spectrochim. Acta - Part A Mol. Biomol. Spectrosc., 130 (2014) 116-121.

59. S. Ahmed, M. Ahmad, B.L. Swami, S. Ikram, A review on plants extract mediated synthesis of silver nanoparticles for antimicrobial applications: A green expertise, J. Adv. Res., 7 (2016) 17-28.

60. D. MubarakAli, N. Thajuddin, K. Jeganathan, M. Gunasekaran, Plant extract mediated synthesis of silver and gold nanoparticles and its antibacterial activity against clinically isolated pathogens, Colloids Surfaces B Biointerfaces, 85 (2011) 360-365.

61. P. Logeswari, S. Silambarasan, J. Abraham, Synthesis of silver nanoparticles using plants extract and analysis of their antimicrobial property, J. Saudi Chem. Soc., 19 (2015) 311-317.
62. S. Prabhu, E.K. Poulose, Silver nanoparticles: mechanism of antimicrobial action, synthesis, medical applications, and toxicity effects, Int. Nano Lett., 2 (2012).

63. J.Y. Song, B.S. Kim, Rapid biological synthesis of silver nanoparticles using plant leaf extracts, Bioprocess Biosyst. Eng., 32 (2009) 79-84.

64. N.G. Bastús, F. Merkoçi, J. Piella, V. Puntes, Synthesis of highly monodisperse citrate-stabilized silver nanoparticles of up to $200 \mathrm{~nm}$ : Kinetic control and catalytic properties, Chem. Mater., 26 (2014) 2836-2846.

65. X. Dong, X. Ji, H. Wu, L. Zhao, J. Li, W. Yang, Shape control of silver nanoparticles by stepwise citrate reduction, J. Phys. Chem. C, 113 (2009) 6573-6576.

66. K.C. Song, S.M. Lee, T.S. Park, B.S. Lee, Preparation of colloidal silver nanoparticles by chemical reduction method, Korean J. Chem. Eng., 26 (2009) 153-155.

67. F. Mehr, M. Khanjani, P. Vatani, Synthesis of Nano-Ag particles using Sodium Borohydride, Orient. J. Chem., 31 (2015) 1831-1833.

68. K.D. Bhatte, K.M. Deshmukh, Y.P. Patil, D.N. Sawant, S.I. Fujita, M. Arai, B.M. Bhanage, Synthesis of powdered silver nanoparticles using hydrogen in aqueous medium, Particuology, 10 (2012) 140-143.

69. C.D. Kane, R.L. Jasoni, E.P. Peffley, L.D. Thompson, C.J. Green, P. Pare, D. Tissue, Nutrient solution and solution $\mathrm{pH}$ influences on onion growth and mineral content, J. Plant Nutr., 29 (2006) 375-390.

70. S. Kuunal, S. Kutti, M. Guha, P. Rauwel, D. Wragg, G. Nurk, E. Rauwel, Silver Nanoparticles Study for Application in Green Housing, ECS Trans., 64 (2015) 15-24.

71. F.W. Chattaway, Antibiotics and Antimicrobial Action, Biochem. Educ., 6 (1978) 61.

72. S. Gunalan, R. Sivaraj, V. Rajendran, Green synthesized ZnO nanoparticles against bacterial and fungal pathogens, Prog. Nat. Sci. Mater. Int., 22 (2012) 693-700.

73. K.-S. Lee, M.A. El-Sayed, Gold and Silver Nanoparticles in Sensing and Imaging: Sensitivity of Plasmon Response to Size, Shape, and Metal Composition, J. Phys. Chem. B, 110 (2006) 19220-19225.

74. S.L. Smitha, K.M. Nissamudeen, D. Philip, K.G. Gopchandran, Studies on surface plasmon resonance and photoluminescence of silver nanoparticles, Spectrochim. Acta - Part A Mol. Biomol. Spectrosc., 71 (2008) 186-190.

75. K.-C. Lee, S.-J. Lin, C.-H. Lin, C.-S. Tsai, Y.-J. Lu, Size effect of $\mathrm{Ag}$ nanoparticles on surface plasmon resonance, Surf. Coatings Technol., 202 (2008) 5339-5342. 